\title{
UN environmental policv: Non-State Actors, trends, and the regulatory role of the state
}

\author{
Joseph S. Weiss ${ }^{\text {a }}$ \\ Zhu Dajian $^{\text {b }}$ \\ Maria Amélia Enríquez ${ }^{\text {c }}$ \\ Peter H. May ${ }^{\text {d }}$ \\ Elimar Pinheiro do Nascimento ${ }^{\text {a }}$ \\ Walter A. Pengue ${ }^{\mathrm{e}}$ \\ Stanislav Shmelev ${ }^{\mathrm{f}}$ \\ ${ }^{a}$ Universidade de Brasilia, Brazil \\ b Tongji University, China \\ ${ }^{\mathrm{c}}$ Universidade Federal do Pará, Brazil \\ ${ }^{\mathrm{d}}$ Universidade Federal Rural do Rio de Janeiro, Brazil \\ ${ }^{\text {e }}$ Universidad Nacional General Sarmiento, Argentina \\ ${ }^{\mathrm{f}}$ University of Edinburgh, UK
}

\begin{abstract}
This interdisciplinary article draws from the radical ideas of global political ecology (GPE), environmental politics, ecological economics and the sociological analysis of social movements. It seeks to help bridge the research gap regarding non-state actors' (NSAs) influence on the role of the nation-state and the United Nations in global political ecology and environmental policy, including emission reductions, such as antideforestation measures, and environmental justice. We consider NSAs as consisting of two heterogeneous global coalitions: a) civil society organizations (CSOs) and environmental non-governmental organizations, and b) peak corporate organizations with green economy objectives, here denominated green business organizations, representing transnational corporations (TNCs). After a review of prior studies, we present a version of an advocacy coalition framework; identify a timeline of changes in UN architecture and simplified NSA influence categories. We only begin to test very broad hypotheses on relative agency and to compare NSA narratives with UN documents. We show that the architecture of the UN has gradually shifted from favoring civil society to corporations. There is evidence that, in the late 1990s, in comparison with CSOs, TNCs increased their access to nation-states and UN agencies. The TNC narrative changed from a) denying climate change and ignoring the UN to b) recognizing change and guiding negotiations. These shifts in UN architecture, TNC agency and narrative appears to have influenced changes in UN documents towards a corporate global environmental framework, reducing their references to the regulatory and enforcement roles of the state and global binding agreements, shifting global debate towards a voluntary corporate orientation. This may have reduced prospects for reducing emissions and increasing environmental justice. Combining market mechanisms with strong regulatory frameworks is best practice for environmental policy. When nation-states have the will and capacity to command and control, they can reduce environmental degradation.

\footnotetext{
${ }^{1}$ Dr. Joseph S. Weiss, Center for Sustainable Development, Universidade de Brasilia (CDS/UnB), Brazil. Email: josephweissbr "at" gmail.com. Dr. Zhu Dajian, Distinguished Professor, Department of Public Management, Tongji University, China. Dr. Maria Amélia Enríquez, Professor of Economics, Universidade Federal do Pará, Brazil. Dr. Peter H. May, Professor, Graduate Program in Social Sciences in Development, Agriculture and Society, Universidade Federal Rural do Rio de Janeiro (CPDA/UFRRJ), Brazil. Dr. Elimar Pinheiro do Nascimento, Associate Professor of Sociology, Universidade de Brasilia, Brazil. Dr. Walter A. Pengue, Professor, Instituto del Conurbano, Universidad Nacional General Sarmiento, Argentina. Dr. Stanislav Shmelev, visiting lecturer, University of Edinburgh, UK. Acknowledgements: Thanks to the participants at the XI National Meeting of the Brazilian Society of Ecological Economics in Araraquara, São Paulo, Brazil (2015) and the 14th International Society of Ecological Economics (ISEE) in Washington (2016) for their helpful comments on previous versions of this article presented there. Also, to Prof. Sharon Beder, Prof. John Foran, two reviewers and an anonymous reader, for their significant suggestions;and Profs. Casey Walsh and Simon Batterbury, $J P E$ editors, for their generous time and attention.
} 
Stronger national government competence and enforcement capacity and binding UN agreements are essential for the effectiveness of market incentives, which may be enhanced by business and civil society initiatives. If CSOs can reunite and regain their strength, maybe they could negotiate with TNCs on a more equal footing. Perhaps UN members could once again become comfortable with the idea of strong states and non-hegemonic global governance.

Key words: Global political ecology, Nation-state, earth system governance, UN architecture, UN agency, green economy, non-state actors, UNCED, Rio+20, Climate convention

\section{Résumé}

Cet article interdisciplinaire s'inspire des idées radicales de global political ecology, de la politique environnementale, de l'économie écologique et de l'analyse sociologique des mouvements sociaux. Il cherche à combler l'écart de recherche concernant l'influence des acteurs non étatiques (ANE) sur le rôle de l'Étatnation et des Nations Unies dans global political ecology et la politique environnementale, y compris les réductions d'émissions, telles que les mesures anti-déforestation et la justice environnementale. Nous considérons les ANE comme constitués de deux coalitions mondiales hétérogènes: a) les organisations de la société civile (OSC) et les organisations non gouvernementales environnementales (ONGE), et b) les principales organisations d'entreprises avec des objetifs d'economie verte, dénommées les organisations commerciales vertes, représentant les sociétés transnationales (STN). Après un examen des études antérieures, nous présentons une version d'un «cadre de coalition de plaidoyer»; identifions un calendrier des changements dans l'architecture de l'ONU et des catégories d'influence simplifiées des ANE. Nous commençons seulement à tester des hypothèses très larges sur l'agence relative et à comparer les récits des organisations commerciales vertes avec les documents de l'ONU. Nous montrons que l'architecture de l'ONU s'est progressivement déplacée de favoriser la société civile aux entreprises. Il y a d'evidence qu'à la fin des années 1990, par rapport aux OSC, les STN ont augmenté leur accès aux États-nations et aux agences des Nations Unies. Le récit de la STN a changé de a) refuser le changement climatique et ignorer l'ONU à b) reconnaître le changement et orienter les négociations. Ces changements dans l'architecture des Nations Unies, l'agence STN et leur récit semblent d'avoir influencé les changements dans les documents de l'ONU vers un cadre de l'entreprise, en réduisant leurs références aux rôles réglementaires et exécutifs de l'État et aux accords internationaux contraignants, en passant du débat mondial vers une orientation volontaire de l'entreprise. Cela pourrait avoir réduit les perspectives de réduction des émissions et d'accroissement de la justice environnementale. La combinaison des mécanismes de marché avec des cadres réglementaires solides est la meilleure pratique pour la politique de l'environnement. Lorsque les États-nations ont la volonté et la capacité de commander et de contrôler, ils peuvent réduire la dégradation de l'environnement. Une compétence accrue des pouvoirs publics nationaux, des capacités d'exécution et des accords contraignants de l'ONU sont essentiels à l'efficacité des incitations au marché, qui peuvent être renforcées par les initiatives des entreprises et de la société civile. Si les OSC peuvent se réunir et retrouver leur force, peut-être qu'elles pourraient négocier avec les sociétés transnationales sur une base d'égalité. Peut-être que les membres de l'ONU pourraient encore être à l'aise avec l'idée d'états forts et de gouvernance mondiale non hégémonique.

Mots clés: Écologie politique mondiale, État-nation, gouvernance du système terrestre, architecture de l'ONU, agence des Nations Unies, économie verte, acteurs non étatiques, Sommet Planète Terre, Rio + 20, convention climatique

\section{Resumen}

Este artículo interdisciplinario se basa en las ideas radicales de la ecología política global, la política ambiental, la economía ecológica y el análisis sociológico de los movimientos sociales. Su objetivo es ayudar a superar la brecha de estudios sobre la influencia de los actores no estatales (ANE) en el papel del Estadonación y de las Naciones Unidas, en lo que se refiere a la ecología política global, incluyendo reducciones de emisiones, y a la política ambiental, como la lucha contra la deforestación. Consideramos como actores no estatales como constituyendo de dos coaliciones globales muy heterogéneas: a) las organizaciones de la sociedad civil (OSC) y organizaciones no gubernamentales ambientales (ONGE), y b) aquellas que representan a corporaciones transnacionales (CTN), denominados aquí de organizaciones empresariales verdes. Después de una revisión de estudios previos, presentamos una adaptación del advocacy coalition framework; identificamos una línea de tiempo de los cambios en la arquitectura de la ONU y categorías simplificadas de influencia. Empezamos a testar hipótesis muy amplias sobre la agencia relativa y a comparar las narrativas de esos atores con los documentos de la ONU. Sólo comenzamos a probar hipótesis muy 
amplias sobre la agencia relativa ya comparar las narrativas de las CTN con los documentos de la ONU. Mostramos que la arquitectura de la ONU ha ido pasando gradualmente de favorecer a la sociedad civil a favorecer a las corporaciones. En cuanto a la agencia, hay evidencias de que, a finales de los años noventa, en comparación con las OSC, las CTN aumentaron su acceso a los estados-nación y a los organismos de las Naciones Unidas. La narrativa de las CTN cambió de negar el cambio climático y de ignorar a la ONU a una de reconocer el cambio y de guiar las negociaciones. Estos cambios en la arquitectura de las Naciones Unidas, y la agencia y la narrativa de las CTN, parecen haber influido en cambios en los documentos de la ONU hacia un marco de economía verde, reduciendo sus referencias a las funciones regulatorias, la responsabilidad del estado y a acuerdos globales vinculantes. Esto puede haber disminuido las perspectivas para reducir emisiones y aumentar la justicia ambiental. La combinación de mecanismos de mercado con marcos regulatorios fuertes es una buena práctica para la política ambiental. Cuando los estados-nación tienen la voluntad y la capacidad de disuadir, pueden reducir la degradación ambiental. El fortalecimiento de la capacidad de los gobiernos nacionales de hacer cumplir la ley como también los acuerdos vinculantes de las Naciones Unidas son esenciales para la eficacia de los incentivos de mercado; ayuda, más aún, cuando complementados por iniciativas empresariales y de la sociedad civil. Si las organizaciones de la sociedad civil pueden volver a unirse y recuperar fuerzas, quizás podrían negociar con las CTN en pie de igualdad; y, quién sabe, los miembros de la ONU podrían volver a sentirse cómodos con la idea de estados fuertes y gobernanza global no hegemónica.

Palabras clave: Ecología política global, Estado-nación, gobernanza del sistema global, arquitectura y agencia de las Naciones Unidas, economía verde, actores no estatales, Cumbre de la Tierra, Rio+20, convención climática

\section{Resumo}

Este artigo interdisciplinar baseia-se nas ideias radicais de ecologia política global (EPG), política ambiental, economia ecológica e análise sociológica dos movimentos sociais. Pretende ajudar a fechar a lacuna de estudos sobre a influência dos atores não estatais (ANE) no papel do Estado-nação e das Nações Unidas, incluindo na redução de emissões, e na política ambiental, tal como medidas contra o desmatamento. Consideramos os ANE como consistindo de duas coalizões globais muito heterogêneas: a) organizações da sociedade civil (OSC) e organizações não-governamentais ambientais (ONGE), e b) organizações corporativas de pico, aqui denominadas organizações empresariais verdes, representando empresas transnacionais (ETN). Após uma revisão de estudos anteriores, apresentamos uma versão do advocacy coalition framework; identificamos uma linha de tempo de mudanças na arquitetura da ONU e categorias simplificadas de influência. Apenas começamos a testar hipóteses muito amplas sobre a agência relativa e a comparar as narrativas desses atores com documentos da ONU. Mostramos que a arquitetura da ONU mudou gradualmente de favorecer a sociedade civil para favorecer corporações. No que se refere à agência, há evidências de que, no final da década de 1990, em comparação com as OSC, as ETN aumentaram seu acesso a estados-nação e agências da ONU. A narrativa das ETN mudou de a) negar a mudança climática e ignorar a ONU para b) reconhecer a mudança e orientar as negociações. Essas mudanças na arquitetura da ONU e na agência e na narrativa das ETN parecem ter influenciado mudanças em documentos da ONU, reduzindo suas referências aos papeis de regulação e de fazer cumprir, como também a acordos globais vinculantes, deslocando o debate global para uma orientação corporativa voluntária. Isso pode ter diminuído as perspectivas para reduzir as emissões e aumentar a justiça ambiental. A combinação de mecanismos de mercado com marcos regulatórios fortes é uma prática recomendada para a política ambiental. Quando os estados-nação têm a vontade e a capacidade de comando e controle, eles podem reduzir a degradação ambiental. Uma maior competência do governo nacional e capacidade de execução e acordos vinculantes da ONU são essenciais para a eficácia dos incentivos de mercado, que podem ser reforçados por iniciativas empresariais e da sociedade civil. Se as OSC puderem voltar a se unir e recuperar forças, talvez possam negociar com as TNCs em pé de igualdade. Talvez os membros da ONU possam voltar a se sentir confortáveis com a ideia de estados fortes e governança global não-hegemônica.

Palavras-chave: Ecologia política global, Estado-nação, governança do sistema terrestre, arquitetura da ONU, agência das Nações Unidas, economia verde, atores não estatais, Cúpula da Terra, Rio + 20, convenção climática. 


\section{Introduction}

The logic of unrestrained and minimally regulated economies has led to accelerated climate change and increasing income disparities (Orr 2017: 16). The objective of this global political ecology study is to analyze trends regarding the influence of non-state actors (NSA) on United Nations environmental policy, including anti-deforestation measures, their different views on the roles that the UN and the state play in national environmental policies, and the implications for policy effectiveness. We review literature on the roles of NSAs in two decision-making processes which led up to the Rio-92 conference, and continue to this day:

- The preparatory committee (PrepCom) which drafted UN Conference on Environment and Development documents: The Earth Charter preamble, Agenda 21 and the Forest Principles (hereafter Earth Summit documents). This process was followed later by Johannesburg, Rio+20 and the Sustainable Development Goals.

- The UN Framework Convention on Climate Change (UNFCCC), prepared initially by United Nations Environment Programme and the World Meteorological Organization, with the assistance of the Intergovernmental Panel on Climate Change (IPCC), later transferred to the Intergovernmental Negotiating Committee (INC) under the General Assembly. This was followed by the 21 conferences of parties (COPs), culminating in the 2015 Paris Accord (Lago 2007).

We focus particularly on evaluations of TNCs, CSOs and their networks' influence during these two key global processes. We do not review the Convention on Biological Diversity preparation process by another INC. We then present a set of methods and hypotheses that allow us to discern a possible shift in global influence upon UN negotiations from civil society to corporate organizations. It analyses the agents, their agency and their influence on agenda-setting, negotiations, position development, policy-making processes and outcomes. The key issue in this analysis is the identification of circumstances and institutions that have power-relevant effects (Sibeon 1999: 140).

The article is relevant to UN agreements and guidance on country and sector decisions regarding the controversial policy choice of whether to apply regulations and/or market incentives. These decisions will affect the prospects for a favorable global ecological policy framework and the slowing of climate change. Thus, we deal with issues of global system governance, prospects for a desirable future (Bai et al. 2015) and an ideological transition in the Anthropocene (Biermann 2015). Gell-Mann's question is applicable: "Can we discuss issues of global governance without considering politics in the various countries and regions, or without looking at the competition and conflict between differing ideologies (2010: 3)?"

\section{Global political ecology, interdisciplinarity, and terms}

This interdisciplinary article draws from the radical ideas of global political ecology, environmental politics, ecological economics and the sociological analysis of social movements. Bryant and Bailey (1997) considered global political ecology and ecological economics as sharing a radical and ecocentric perspective. In brief, global political ecology draws on theories of social and political change to understand the systemic causes of inequality and environmental degradation around the world, looking at the drivers of environmental conflict resulting in unjust burdens on communities and nations. It supports action research with global environmental and climate justice movements.

Bryant and Bailey also indicate the field's variety of approaches, also visible in a more recent collection (Peet, Robbins and Watts 2011). Concentrating on different actor interests, characteristics and actions and the central importance of politics is helpful to understand non-state actor's influence upon UN processes, and we develop this in an "advocacy coalition framework." The analysis of ideas and discourses used to support interests allows comparison of important coalitions that we discuss below, and their impact on UN documents regarding the regulatory role of the state. 
We also seek to apply critical state theory to understanding influences on the UN. It can be broken into three: structural dependence theory, assuming a degree of state and UN autonomy from commerce and industry; institutionalist theory, in which business acts cohesively to impose its agenda; and cultural/discourse theories, where influence is achieved primarily through ideas, narratives and symbols (Levy and Egan 1998). We consider aspects of ecological economics, especially the consequences of the planet's biophysical limits, and the actions of coalitions of civil society and business. In what follows, we compare the very broad terms of 'sustainable development' and 'green economy', interpret the concepts of architecture, agency, and influence, as well as identifying some of the processes used to achieve agency such as narratives, agenda setting, and framing.

\section{'Sustainable Development' and 'Green Economy'}

The Brundtland Commission defined sustainable development as "development that meets the needs and aspirations of the present without compromising the ability to meet those of the future" (UN World Commission on Environment and Development 1987: 40). Even though the concept is weak, has been weakened further over the years and can be variously interpreted, it was the key concept applied at Rio in 1992 during the Earth Summit where global environmental regulatory regimes were approved, such as the UNFCCC. It still has significant political support, combing support for economic growth, social justice and environmental protection and seeks to ameliorate poverty in the developing countries while simultaneously conserving natural resources, celebrating diversity and expanding public participation (Egelston 2013).

Many years on, the green economy emphasizes growth, technology and innovation, promoting the effectiveness of private voluntary actions. "The green economy approach seeks, in principle, to unite under a single banner the entire suite of economic policies and modes of economic analyses of relevance to sustainable development (UN Secretary-General 2010:15)." Does this mean that policies not under that banner are not considered? Also, many green economy policies, although seeking to meet ecological objectives, fail to consider social ones (Benson et al. 2014). In many respects, political ecologists argue the green economy has supplanted sustainability objectives, and allowing corporations new opportunities for investment (Cavanagh and Benjaminsen 2017, and associated special issue).

\section{Earth System Governance, architecture, agency, and influence}

The Global Governance Commission (1995) conceived of environmental governance as the sum of diverse forms by which people and institutions, public and private, manage their common interests. They define Earth System Governance as the "interrelated and increasingly integrated system of formal and informal rules, rule-making systems, and actor-networks at all levels of human society (from local to global) that are set up to steer societies towards preventing, mitigating, and adapting to global and local environmental change." It is seen "as the capacity to ...produce effects that ultimately shape natural processes." It includes formal institutions with the power to enforce the law as well as informal arrangements. (World Commission on Environment and Development 1987; Biermann et al. 2009; Dellas, Pattberg and Betsill 2011: 89-95). Brand sees this approach as a new Foucauldian hegemonic discourse and process, as well as being a very weak form of re-regulation (2005: 157).

Architecture and agency are two of several constructs that influence Earth System Governance policymaking and implementation (Biermann et al. 2009). Architecture in this context includes issues relating to the emergence, design, and effectiveness of governance systems as well as the overall integration of global, regional, national, and local governance. Agency analysis seeks to answer which social or individual actors have the capacity to decide and act upon situations, and are responsible for particular outcomes. Agents are those "who actively shape norms and values related to a particular environmental issue", where agency could be "a dynamic trait that can be created and lost and to explore how this is shaped by environmental change." (Biermann et al. 2009). This suggests that the influence of business on autonomous states or the UN can be tempered, or their autonomy is limited (Dellas Pattberg and Betsill 2011: 89, 95; Hindess 1986: 155). 
Betsill and Corell evaluate the effectiveness of agency and define influence as that which "occurs when one actor intentionally communicates to another so as to alter the latter's behavior from what would have otherwise occurred" (2008: 24).

\section{Narrative analysis, agenda setting and framing}

Narratives, agenda setting, and framing are key elements of decision-making power regarding national and international public policy. Narrative analysis examines an argumentative structure, whether verbal or written, for example in a political process, showing how bias may be mobilized. It considers what the speaker means and the positions he/she reflects, combined with the extra-discursive social practices from which social constructs emerge, tied to specific institutions and actors (Hajer 1993). A discourse becomes dominant if key actors accept the new storyline, called discourse structuration. Narratives have the power to shape beliefs and actions. The narrative policy framework is a quantitative, structuralist, or positivist approach to the study of policy narratives (Jones and McBeth 2010). In political ecology narratives are seen as 'storylines' that guide the assertion or economic and political power, justifying and shaping political and economic control over material resources, and justifying power differentials (Escobar 1996).

"Power... can be understood in three ways: (1) articulating and providing information regarding one's interests; (2) agenda setting and/or vetoing initiatives; and (3) receiving ...or engendering ideological support for one's policies" (Cowles 1995). "The agenda setting process is an ongoing competition among issue proponents to gain the attention of media professionals, the public, and policy elites" (Dearing and Rogers 1996). Agenda-setting tells us what to think about. The stakeholder's power is to set the political agenda by deciding which problems or issues should receive the attention of authorities and which should not. In essence, agenda-setting is the predominant strategy for achieving policy aims.

At a second level, framing is how to think about it. It is conceived as a process whereby circumstances are defined according to an organization's principles (Goffman 1986: 1-11). Snow defined it as a group's conscious strategic efforts to formulate shared understandings of the world and of itself, which legitimate and motivate collective action (Snow et al. 1986). Others see it as a process in which social actors, media and society interpret, define and redefine the situation (Klandermans 1997: 44; Tarrow 1998: 17). Frames influence opinions by stressing specific values and interpreting facts, making them apparently more relevant than an alternative frame. These conceptions of framing are valid for social movements and for business initiatives. Weiss and Nascimento suggested interpreting the meaning of framing as the processes by which organizations or groups formulate their logic of reality and action (2013). This concept parallels the constructivist emphasis on ideas and discourse (Escobar 1996). Some actors use framing to modify the collective understandings of a problem, while others are on the receiving end - accepting or contesting proposals or practices.

\section{Studies of non-state actor influence on UN environmental policy}

There have been many studies on the influence of business and civil society on the UN, and their importance in the development of UN environmental policies and global governance. Many authors concentrate on the influence of TNCs (Beder 2000; Falkner 2008; Newell and Paterson 2010; Sagafi-nejad and Dunning 2008; Weiss T.G. 2011; Weiss T.G. et al. 2009, 2013 and 2014). Others look at the influence of civil society organizations, ENGOs and related advocacy networks (Arts 1998; Betsill and Corell 2008; Castro 2015; Corell and Betsill 2001; Keck and Sikkink 1998 and Sikkink 2002). The effectiveness of global advocacy networks can be evaluated in their "framing of debates, getting issues on the agenda, encouraging actors to make discursive commitments, causing procedural change, affecting policy and influencing actor behavior." (Keck and Sikkink 1998: 215). Transnational advocacy groups help initiate a shift in norms. Non state actors are crucial to create norms and discourses, engaging in a process of restructuring world politics (Sikkink 2002). NSA influence is considered stronger when linked to their ability to speak with one voice (Arts 1998). 


\section{Civil Society Organizations and ENGOs}

"From an early stage, international climate diplomacy has been focused on the creation of a comprehensive treaty with binding commitments" supported by civil society organizations and environmental NGOs, at least since the founding of the Climate Action Network (CAN) in 1989 (Falkner et al. 2010: 2; Nulman 2015). ENGOs, often allied with the European Union, were then seen as representing those immediately affected. On the other hand, transnational corporate objectives, with the support of the U.S. and other delegations, have sought to avoid binding commitments. While there was an initial divide between global north and south CSOs on environment versus development concerns, during the 1990s they ended up united on many issues.

Corell and Betsill built an analytical framework which compares two dimensions of environmental NGO influence in the 1990s: participation in international negotiations and their subsequent effects on the behavior of other actors. Using documents, interviews, and participant observation, they traced processes and carried out counterfactual analysis to find that environmental NGOs shaped the 1992 Earth Summit the Earth Summit negotiation process (through issue framing, agenda setting or by shaping the positions of key states) and/or the final outcome (procedural and substantive text elements) (2001: 89). Arts (2008), using a similar approach, carried out a detailed analysis of the climate and biodiversity convention negotiations prior to the Earth Summit. He recognizes that many ENGOs were involved in the preparation of the climate and biodiversity conventions, even in the drafting of some documents, but the outcomes would not have been much different without them, suggesting their influence was episodic rather than permanent and more power. Authors admit that the NGO role probably decreased since Rio.

\section{Transnational corporations and green business organizations}

Sagafi-nejad and Dunning (2008) provide an analytical history of the UN's relationship with transnational corporations and their relationships with developing countries. They see the UN as a balancer of views and a moderator of actor reactions. They divided the history into five phases (from before WWII to the present).

Levy and Egan argue that many large companies feared the emergence of an international environmental regulatory structure and that, in the PrepCom negotiations and at the Earth Summit, "the international institutions involved in the climate change negotiations were relatively insulated from structural pressures..." (2000: 139, 145). Nevertheless, while less concerned with the PrepCom for other Rio documents, the World Business Council for Sustainable Development (WBCSD, a key green business organization) and its fossil fuel industry members used their influence during UNFCCC negotiations to limit commitments to concrete action (Mintzer and Leonard 1994).

\section{Green business organizations and environmental NGOs compared}

Few authors compare the influence of green business organizations and environmental NGOs (Gupta 2010; Levy and Egan 2000; Nasiritousi et al. 2014). Newell (2000) reports on both, without directly comparing them. Levy and Egan argue that Maurice Strong and Stephan Schmidheiny, at the head of the Earth Summit, representing TNCs, gave companies special status that environmental NGOs lacked (2000: 112-114). These authors recognize, nevertheless, that at that time, "despite the vast resources available to business groups, most observers concur that their influence has not overwhelmed the voice of environmental ENGOs..." such as the Global Climate Coalition. Almeida indicates that "only one leader, the Swiss Stephan Schmidheiny, spoke for business at Rio-92... [and] that the UN recommended that partnerships between governments and NGOs also involve business", suggesting that ENGOs were already involved.

In her analysis of history of international climate change policy, Gupta selects "the increasing engagement of different social actors and the gradual use of market mechanisms" as one of the five key issues (Gupta 2010: 636). She develops a timeline of the climate change regime process, dividing the late 1980s through 2008 into five periods. In Table 1, we adapt her timeline, presenting her comments on these key issues. She finds that ENGOs were initially more active while industry was less interested, later becoming more so. Gupta concludes that "market mechanisms have been perhaps more successful in raising the profile 
of awareness of the climate change issue than the public relations activities carried out under the regime," even though they must face weaknesses such as lack of perfect information, the focus on profit maximization, speculation, etc. (2010: 640).

Newell (2000: 105) considers that green business organizations preempted UNFCCC contents, thus excluding binding agreements and carbon tax from the agenda. Meanwhile, riding a wave of popular concern and with their close relations with policy makers, ENGOs influenced agenda-setting on per capita emissions and extracted some commitments. ENGOs, backed by technical knowledge and allied with G77 and China, also achieved inclusion of joint implementation. Later, at Berlin (COP1), NGOs, the U.S., Brazil and India supported binding agreements, achieving the Berlin mandate (Brenton 1994; Newell 2000: 131,142).

\begin{tabular}{|c|c|c|c|}
\hline Period & $\begin{array}{c}\text { The } \\
\text { paradigm }\end{array}$ & Relevant NSA and market mechanism comments & Outcomes \\
\hline $\begin{array}{l}\text { 1) } 1989- \\
1990\end{array}$ & $\begin{array}{c}\text { Framing the } \\
\text { problem }\end{array}$ & $\begin{array}{l}\text { "ENGOs were beginning to be active. The Climate } \\
\text { Action Network was established in March } 1989 \text { (as a } \\
\text { coalition of many different ENGOs)...Industry, on the } \\
\text { other hand, was scarcely engaged in the issue at that } \\
\text { time." (Gupta 2010: 637) }\end{array}$ & $\begin{array}{l}\text { Nairobi PrepCom I } \\
\text { set the Earth } \\
\text { Summit terms of } \\
\text { reference }\end{array}$ \\
\hline $\begin{array}{l}\text { 2) } 1991- \\
1996\end{array}$ & $\begin{array}{l}\text { Leadership } \\
\text { articulated }\end{array}$ & $\begin{array}{l}\text { "the international institutions involved in the climate } \\
\text { change negotiations were relatively insulated from } \\
\text { structural pressures"(Levy and Egan 2000: 145). }\end{array}$ & $\begin{array}{l}\text { UNFCCC; Earth } \\
\text { Summit 1992: } \\
\text { Convention on } \\
\text { Biological } \\
\text { Diversity (CBD), } \\
\text { SD concept } \\
\text { COP2 1996: legally } \\
\text { binding emissions } \\
\text { reductions }\end{array}$ \\
\hline $\begin{array}{l}\text { 3) } 1997- \\
2001\end{array}$ & $\begin{array}{l}\text { Conditional } \\
\text { leadership }\end{array}$ & $\begin{array}{l}\text { Industry was more proactive... Market mechanisms to } \\
\text { address climate change and related research were } \\
\text { emphasized, much more than regulatory instruments } \\
\text { (Gupta 2010: 645-6). "...members of the WBCSD, } \\
\text { heads of state and the UN Secretary-General met [in } \\
\text { 1997] to establish business participation in the UN } \\
\text { policy setting process (Korten 1997; Levy and Egan } \\
\text { 2000: 151)." }\end{array}$ & $\begin{array}{l}\text { COP3 1997: Kyoto } \\
\text { Protocol } \\
2000 \text { Global } \\
\text { Compact }\end{array}$ \\
\hline $\begin{array}{l}\text { 4) 2002- } \\
2007\end{array}$ & $\begin{array}{l}\text { Leadership } \\
\text { competition }\end{array}$ & $\begin{array}{l}\text { Considerable research, mostly focused on market } \\
\text { instruments; very few discussed regulatory } \\
\text { instruments. High expectations that market } \\
\text { mechanisms could reduce emissions (Gupta 2010: } \\
647 \text { ). }\end{array}$ & $\begin{array}{l}\text { COP } 15 \text { 2009: } \\
\text { Copenhagen Accord }\end{array}$ \\
\hline $\begin{array}{l}\text { 5) 2008- } \\
\text { present }\end{array}$ & $\begin{array}{l}\text { Leadership } \\
\text { during } \\
\text { recession: }\end{array}$ & $\begin{array}{l}\text { Leadership enhanced by recession. Annex } 1 \text { countries } \\
\text { accept some responsibility. Green economy became } \\
\text { the dominant concept applied at Rio+20 (Weiss and } \\
\text { Nascimento 2013). }\end{array}$ & $\begin{array}{l}\text { Rio+20 2012: green } \\
\text { economy concept }\end{array}$ \\
\hline
\end{tabular}

Table 1: Relevant comments and outcomes on Gupta's timeline of the climate change regime. Sources: Columns 1 and 2: Gupta 2010; Levy and Egan 2000); columns 3-4 added for this article. Note: 'leadership' was a euphemism for the industrialized countries' greater responsibility for emissions. 
Nasiritousi et al. compared the roles of ENGOs and green business organizations at two UNFCCC meetings: COP17 held in South Africa in 2011 and COP18 held in Qatar in 2012. Through surveying selfperceptions at the main and side-events, they found that while ENGOs were strong on raising awareness and representing public opinion, green business organizations were twice as important in agenda-setting and influencing policy makers (Nasiritousi et al. 2016).

\section{Methods and hypotheses}

Most scholars recognize that corporate and civil society organizations influence UN policies and positions, which, in turn, influence many national and local policies, including those with direct and indirect There is a research gap concerning the influence, roles and responsibilities, authority, and strategies of actors regarding Earth System Governance, away from national governments (Biermann et al. 2009). We seek to contribute towards bridging this gap regarding the role of the state and the UN in implementing environmental policy by looking at the architecture of agency in Earth System Governance and the exercise of it.

\section{Our version of the advocacy coalition framework}

To accomplish this objective, we adapt the advocacy coalition framework (Weible et al. 2011) with the following set of tools and analyses:

1) A simplified subsystem typology of the UN political system, defining two very broad and heterogeneous coalitions, civil society and TNCs. We discuss changes in these coalitions since the 1990s.

1) A timeline used to view how UN architecture has gradually changed.

2) Relative coalition influence categories, simplified from categories defined by Betsill and Corell in their assessment of the influence of NGO diplomats during UN negotiations on conventions and documents prior to the 1992 Earth Summit (Betsill and Corell 2008).

3) We subjectively extend these agency categories to a comparison of relative Non State Actor influence at the UN, from Stockholm to Paris, based on reports of their interactions during UN environmental negotiations and conferences.

4) A review of NSA discourse, policy shifts and strategies.

5) A comparison of NSA narratives and UN documents, especially during the Earth Summit, at Rio+20 and Climate Change negotiations since the 1990s.

Although it is empirically difficult to determine which NSAs influence policy decisions, one may formulate hypotheses regarding the causal responsibility for politically significant outcomes (Sibeon 1999). ${ }^{2}$

\section{The United Nations' political subsystems}

We conceive a highly simplified typology of the UN political system, as consisting of five heterogeneous subsystems, shown in Figure 1:

1) The UN secretariats, agencies, conferences and conventions and units. The UN can be separated into enabling trade and investment institutions and regulatory institutions, responsible for social, labor and environmental policies (Levy and Egan 1998). This article deals with regulatory institutions.

\footnotetext{
${ }^{2}$ This strategy is applied by Nepstad et al. (2014) in their analysis of reasons for reduced deforestation in the Amazon.
} 
2) The nation-states, members of the UN, and their groups, continue their traditional role in developing, proposing and approving UN positions, conferences and policies. We divide them into two very heterogeneous and varying groupings: ${ }^{3}$

a. Nation-States 1 (NS1): The developed "north", including the early members, corresponding roughly to those included in Annex 1 of the Kyoto Protocol, and their groups, with differences on issues such as binding commitments.

b. The Nation-States 2 (NS2): The developing "south", many of whose members gained independence after World War II, corresponding roughly to those excluded from Annex 1 of the Kyoto Protocol, including groups of nations.

Instead of considering all NGOs as one subsystem, we artificially group non-state actors (NSAs) into two types of coalitions and advocacy networks, which are often crucial allies with key states to influence UN decision-making (Burgiel 2008):

3) Civil Society Organizations (CSOs): Those which represent environmental issues from the point of view of civil society, including ENGOs, human rights, environmental justice, social movements and their networks and indigenous communities. Some NGOs later migrated to GE and some TNC positions. While the IPCC led to an epistemic community strongly influencing climate change negotiations, this has to be left to another article, as well as an analysis of the influence of subnational government organizations and the media.

4) Transnational corporations (TNCs): Including their special interest-promoting peak organizations (sector-wide or broader), especially eco-modernist green business organizations which adopt the ideas of SD and/or GE.

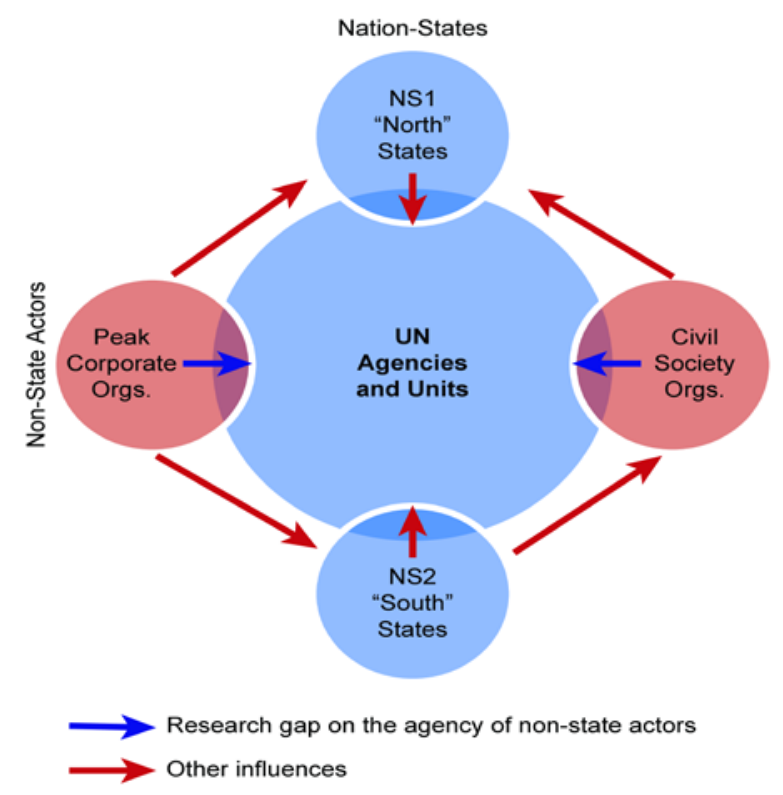

Figure 1: Simplified typology of the UN political system.

We analyze agency by comparing positions on the role of the State according to documents prepared by ENGOs and green business organizations and their influence on official U.N. positions and publications.

\footnotetext{
${ }^{3}$ In her Table 6, Gupta (2010) summarizes the complexity of how members changed groupings from the 1990s to 2008.
} 
Normally, the question of agency would consider relations and their power-relevant effects; but for multilateral issues where effects are long in coming, strategy and intentions, evidenced by published documents, become relevant.

To assess actor influence, we apply Betsill and Corell's concept and a simplified version of their threelevel analytical framework (low, moderate, and high), as shown in Table 2, using indicators such as issue framing and agenda setting (process) and written text (outcome) (2008: 24).

\begin{tabular}{|c|l|l|l|}
\hline \multicolumn{1}{|c|}{ Variable } & \multicolumn{1}{|c|}{ Low } & \multicolumn{1}{c|}{ Moderate } & \multicolumn{1}{c|}{ High } \\
\hline $\begin{array}{l}\text { Participation in } \\
\text { negotiations }\end{array}$ & $\begin{array}{l}\text { Without effect on either } \\
\text { process or outcome }\end{array}$ & $\begin{array}{l}\text { With some success in } \\
\text { shaping process }\end{array}$ & $\begin{array}{l}\text { With some success in shaping } \\
\text { process and outcome }\end{array}$ \\
\hline
\end{tabular}

Table 2: Simplified levels of non-state actor influence. Source: Authors' simplification of Betsill and Corell (2008: 38).

\section{Hypotheses}

Based on this review, we propose the following hypotheses, illustrated in Figure 2, which evaluate trends in the redistribution of power and influence in the UN political system and the consequences to environmental policy effectiveness.

- Green business organizations, an instrument of transnational soft power, have increased their access to nation-states and UN agencies on environmental themes, whereas civil society organizations have become less influential.

- The UN architecture or structure changed gradually from one open to NS2 (global South) and environmental NGO agency to another that favors NS1 (global North) and access by transnational corporations.

- As a result, UN agenda-setting during negotiations, positions and documents tend to emphasize GE and reduce their emphasis on the regulatory role of the nation-state and the UN.

It is given that UN positions regarding the role of the state affect and are affected by the national policies of its members and that interests in each country affect national positions.

- This could possibly lead to less successful efforts to reduce global emissions and increase environmental justice.

These hypotheses are too broad to demonstrate empirically. We can only present some preliminary evidence.

\section{Architectural trends and influence in the UN political system}

Few scholars examine Non State Actors' influence in the processes of UN architectural and institutional change. We build a UN architecture timeline, and examine likely NSA influence. Drawing upon Sagafi-Nejad and Dunning's five phases, we present our understanding of this gradual institutional rearrangement of the UN system. This slow, deliberate process is consistent with the theory of gradual institutional change (Lewis 2002). "Important changes often take place incrementally and through seemingly small adjustments that can, however, cumulate into significant institutional transformation." (Mahoney and Thelen, 2010: xi). We summarize the key events affecting the influence of NSAs on UN environmental policy in the timelines in Table 3. 


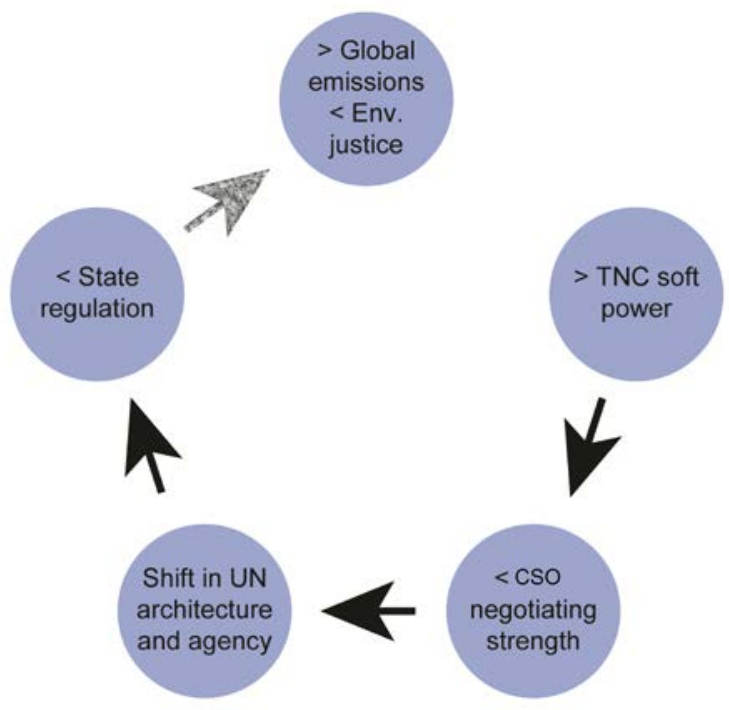

Figure 2: Authors' hypotheses.

\begin{tabular}{|c|c|c|c|c|}
\hline \multirow{2}{*}{ Date } & \multirow{2}{*}{ Key event } & \multirow{2}{*}{ Resulting impact } & \multicolumn{2}{|c|}{ Actors } \\
\hline & & & CSOs & TNCs \\
\hline 1945 & United Nations founded & Strengthened NS1 & none & none \\
\hline $\begin{array}{l}1960- \\
1979\end{array}$ & $\begin{array}{l}70 \text { new UN members (mostly newly } \\
\text { independent) }\end{array}$ & $\begin{array}{l}\text { Strengthened NS2 seeking new } \\
\text { international economic order }\end{array}$ & none & none \\
\hline 1964 & UNCTAD founded & $\begin{array}{l}\text { Positive view towards foreign } \\
\text { direct investment }\end{array}$ & none & low \\
\hline 1972 & $\begin{array}{l}\text { UN Conf. on Human Development } \\
\text { (Stockholm) }\end{array}$ & Civil society influence begins & $\begin{array}{l}\text { mode- } \\
\text { rate }\end{array}$ & none \\
\hline 1972 & UN Environment Program established & $\begin{array}{l}\text { At Nairobi, initially with NS2 } \\
\text { influence }\end{array}$ & $\begin{array}{l}\text { mode- } \\
\text { rate }\end{array}$ & none \\
\hline 1975 & $\begin{array}{l}\text { UN Centre on } \\
\text { Corporations (UNCTC) was founded } \\
\text { and efforts begin to set up Code of } \\
\text { Conduct }\end{array}$ & $\begin{array}{l}\text { Sought left-of-center } \quad \mathrm{UN} \\
\text { regulation of TNCs }\end{array}$ & $\begin{array}{l}\text { mode- } \\
\text { rate }\end{array}$ & none \\
\hline $6-8 / 1990$ & $\begin{array}{l}\text { NGO Forum founded, First Eco92 } \\
\text { Prepcom - Nairobi }\end{array}$ & $\begin{array}{l}\text { NGO conflicts, but some } \\
\text { consensus }\end{array}$ & $\begin{array}{l}\text { mode- } \\
\text { rate }\end{array}$ & low \\
\hline $4 / 1991$ & $\begin{array}{l}\text { Business Council for Sustainable } \\
\text { Development (BCSD) founded. }\end{array}$ & Business voice at Rio92 & $\begin{array}{l}\text { mode- } \\
\text { rate }\end{array}$ & $\begin{array}{l}\text { mode } \\
\text {-rate }\end{array}$ \\
\hline 1992 & $\begin{array}{l}\text { UNCTC closed and TNC Code of } \\
\text { Conduct effort ends }\end{array}$ & Positive frame of TNCs prevails & $\begin{array}{l}\text { mode- } \\
\text { rate }\end{array}$ & $\begin{array}{l}\text { mode } \\
\text {-rate }\end{array}$ \\
\hline $1990-92$ & 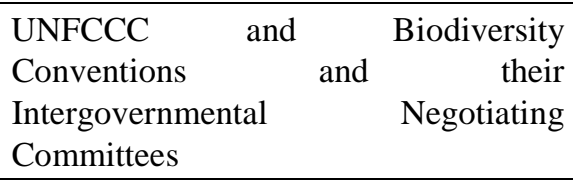 & $\begin{array}{l}\text { CSOs prepare texts while green } \\
\text { business organizations limit } \\
\text { binding agreements }\end{array}$ & high & high \\
\hline 1992 & The Earth Summit & $\begin{array}{l}\text { Strengthens } \\
\text { influence }\end{array}$ & high & $\begin{array}{l}\text { mode } \\
\text {-rate }\end{array}$ \\
\hline
\end{tabular}




\begin{tabular}{|c|c|c|c|c|}
\hline \multirow{2}{*}{ Date } & \multirow{2}{*}{ Key event } & \multirow{2}{*}{ Resulting impact } & \multicolumn{2}{|c|}{ Actors } \\
\hline & & & CSOs & TNCs \\
\hline $7 / 2000$ & UN establishes Global Compact & $\begin{array}{l}\text { Right-of-center UN strengthens } \\
\text { TNCs and self-regulation. }\end{array}$ & $\begin{array}{l}\text { mode- } \\
\text { rate }\end{array}$ & high \\
\hline $8 / 2002$ & $\begin{array}{l}\text { WBCSD publishes Walking the talk: } \\
\text { the business case for SD }\end{array}$ & TNC frame solidified & $\begin{array}{l}\text { mode- } \\
\text { rate }\end{array}$ & high \\
\hline 8-9/2002 & $\begin{array}{l}\text { World Summit on } \quad \text { Sustainable } \\
\text { Development (Johannesburg-Rio+10) }\end{array}$ & The state retains its role & $\begin{array}{l}\text { mode- } \\
\text { rate }\end{array}$ & high \\
\hline 6/2012 & $\begin{array}{l}\text { UN Conference on Sustainable } \\
\text { Development }(\text { Rio+20) }\end{array}$ & $\begin{array}{l}\text { The green economy, with } \\
\text { reduced state role }\end{array}$ & $\begin{array}{l}\text { mode- } \\
\text { rate }\end{array}$ & high \\
\hline
\end{tabular}

Table 3: Key events and relative influence of Non-State Actors on UN environmental policy. Sources: Adams Jr. (2010); Murphy (2005); UN (1972, 1992, 2002, 2010, 2012) and Zammit (2003). Note: BCSD later became WBCSD (World BCSD).

Conceived during World War II, the UN was created when the NS1, and Keynesian policies favoring the developmental role of the state were dominant. In 1964, TNCs supported the creation of the United Nations Conference on Trade and Development (UNCTAD), founded to promote development by expanding trade.

As the result of the UN Conference on the Human Environment in Stockholm in 1972, and the Club of Rome and Brundtland reports, the environment became a worldwide concern. Beginning in the 1960s, NS2 countries and areas of the UN began to adopt an adversarial position towards business. During the 1960s and 1970s, the seventy mostly newly-independent members admitted to the UN strengthened the South. The UN created the United Nations Environment Program (UNEP) with headquarters in Nairobi in 1972 (Table 4). After TNC interference in many countries, such as helping to eliminate Allende in Chile, a New International Economic Order was approved as a declaration of the General Assembly in 1974 and the Center on Transnational Corporations (UNCTC) was established within UNCTAD in 1975, amid efforts to set up a UN Code of Conduct for TNCs. This led many corporate leaders to consider the UN as business-unfriendly with little practical relevance to them and with deteriorating business ties. Business at this time also viewed environmental ideas with general suspicion and hostility (Johnson 1979; Falkner 2008; Kell 2005). This confirms Sagafi-Nejad and Dunning's view of a slightly left-of-center UN in the period (2008).

\begin{tabular}{|l|l|c|c|}
\hline \multirow{2}{*}{ DATE } & \multicolumn{2}{|c|}{ EVENT } & \multicolumn{2}{c|}{ INCREASING INFLUENCE } \\
\cline { 3 - 4 } & & STATE ACTORS & NON-STATE ACTORS \\
\hline 1945 & UN founded & NS1 & \\
\hline 1964 & UNCTAD founded & NS1 & TNCs \\
\hline $1960-79$ & 70 new members & NS2 & ENGOs \\
\hline 1972 & Stockholm, UNEP founded & NS2 & ENGOs \\
\hline 1975 & UNCTC founded & NS2 & ENGOs \\
\hline $1990-1993$ & the Earth Summit & NS1 & TNCs \\
\hline 1992 & WBCSD founded & NS1 & TNCs \\
\hline $1997-2000$ & Global Compact founded & & TNCs \\
\hline 2012 & Rio+20 & & \\
\hline
\end{tabular}

Table 4: Changing UN political architecture. Sources: see Table 3. 


\section{Non State Actor influence and narratives during environmental negotiations}

As examples, we briefly compare the document narratives and frames posed by ENGOs and green business organizations and their influence on UN institutions, including the setting of conference agendas during negotiations for the 1992 Earth Summit and at Rio+20.

\section{ENGOs demands for strong regulations and the decline of their influence}

Most ENGOs originally sought to represent civil society organizations and movements, while defending numerous legally binding global commitments and national regulatory policies. CSOs and ENGOs began early to plan for the 1992 Earth Summit at Rio, with significant participation, beginning at the first Preparatory Committee in Nairobi in August 1990. Their influence came to bear especially at the last PrepCom meeting. They led governments to incorporate significant input directly into the Earth Summit working documents, including the Rio Declaration principles, the poverty chapter of Agenda 21, the Forest Principles, as well as documents on indigenous people and womens' issues. There is even evidence that ENGOs put political pressure on heads of state to attend the summit (Adams Jr. and Martinez-Aragon 1992; Betsill and Corell 2008).

The PrepCom meetings democratized international political procedures with increased NGO participation (IISD 1992). The Earth Summit accredited 1,378 NGOs with the right to participate and be heard. The UN committed itself to involving NGOs within the UN system, including mandating institutions to work more closely with them and allowing them to register with the UN's Economic and Social Council (Betsill and Corell 2008; Egelston 2013; IISD 1992). These NGO achievements seemed considerable then, but less important today. This period, including the 1995 COP1 in Berlin, turned out to be the peak of NGO influence at the UN.

Betsill and Corell comment that higher levels of ENGO influence are more likely when the political stakes of the negotiations are relatively low, as in negotiations over nonbinding principles and/or framework agreements with few demands for behavioral change (2007: 16). Consistently, Arts affirmed that outcomes would not have been much different without them, establishing episodic effects rather than permanent shifts in power (Arts 1998: 27).

Despite losing ground to the GE narrative, at Rio+20, ENGOs still nominally defend strong legally binding commitments, such as in CAN's Rio+20 proposal, with little influence on conference outcomes (CAN 2012: 1). However, as TNC influence and GE concepts became predominant, some ENGOs migrated to the green business organization GE narrative, with only nominal support for regulation and binding commitments, acquiescing to limited accords. UNEP still backed a parallel World Congress on Justice, Governance and Law for Environmental Sustainability, led by Chief Justices and Attorneys General, whose declaration demanded enforcement of standards and safeguards for environmental sustainability (UNEP 2012). The World Wildlife Fund (WWF) Director General Jim Leape reported at Rio+20 that "With too few countries prepared to press for action, [Brazil] ...squandered [an] opportunity [with] an agreement that does not set the world on a path toward sustainable development" (WWF 2012). The Instituto Socioambiental accused Brazil of "a lack of courage to stimulate other countries towards more effective discussions and action" (ISA 2012).

In Paris, many ENGOs agreed to the merely moral obligations of the Intended Nationally Determined Contributions (INDCs), signed by governments then in power. (CAN 2012:1). ${ }^{4}$ This has led some ENGOs and CSOs to break away and form more radical networks such as Climate Justice Now! Rising Tide North America argued that "the climate movement is dead." (Rising Tide North America 2010; Della Porta and Parks 2014). CSO influence has declined.

\footnotetext{
${ }^{4}$ Taking the Brazilian Amazon as an example, ENGOs back government efforts to achieve environmental governance effectiveness, including economic and environmental zoning, public forest management policies, police enforcement of deforestation regulations, extractive reserves, land tenure control and numerous other public regulations and policies, as well as public-private initiatives to enforce green soy, meat and palm oil chains (Friends of the Earth International and Amazon Working Group 1996; Nepstad 2014). Other civil society and indigenous community documents approved before (at Cochabamba, Bolivia - climateandcapitalism.com 2010) and during Rio+20 (Peoples Summit 2012) confront capitalist exploitation of natural resources.
} 


\section{Green Business Organizations change narrative and increase influence}

After initially ignoring UN environmental policy with diverging views, green business organizations turned to acting cohesively around an eco-modernist narrative. Business has achieved a broader relationship with the UN, possibly with some level of institutionalist influence. We divide the changes in business narrative and their increase in influence into three phases:

Phase I - Deny and ignore. During the 1960s and early 1970s, despite initial recognition of global problems such as resource exhaustion by the Club of Rome, most business leaders viewed environmental ideas with suspicion and hostility, attributing little importance to global environmental policy. The climate change-denier frame prevailed, espoused by green business organizations such as the Global Climate Coalition, which closed in 2002 (Falkner 2008; Levy and Egan 1998).

Phase II - Divided between 'deny and ignore' vs 'recognize and join.' Fearing the emergence of environmental regulatory structures beyond their influence, the environmental strategy of some large companies began to change in the 1980s (Levy and Egan 1998). While some TNCs still attributed little importance to the Rio 1992 conference, other corporate leaders were just beginning to learn that decisions taken there could not only affect compulsory international agreements, but also eventually affect individual corporations via new policies at the national level. Consistent with these two views, the denier frame still competed at the Earth Summit with the more saleable, but still new, eco-modernist Sustainable Development frame.

The International Chamber of Commerce and UNEP held a World Industry Conferences on Environmental Management (WICEM) in 1984. In 1991, a Business Charter for Sustainable Development was produced at a second WICEM in which TNCs were characterized "as benign stewards of the Earth with the will and resources to solve environmental problems (Levy and Egan 1998: 354)." It suggested they could better achieve SD than governments (Egelston 2013; Schmidheiny 1992). Almost a year after the Nairobi PrepCom where CSOs predominated, TNCs established, in 1991, the precursor to the World Business Council on Sustainable Development (WBCSD), a key green business organization set up in 1992.

This divided narrative among TNCs. Meanwhile, ENGOs' better informal access to delegates led nation-states to approve significant binding agreements, including the United Nations Conventions on Climate Change and Biological Diversity, as well as the Rio Declaration on Environment and Development, Agenda 21 and Forest Principles (Levy and Egan 1998: 345; Betsill and Corell 2008).

Phase III - Guide and Approve. With most businesses united in strong green business organizations with a clear message, analysis of the Cartagena Protocol negotiations on Biosafety (1995-2000) found that business began to balance its UN influence with civil society; both ENGOs and green business organizations achieved moderate influence, shaping the position of key states and the negotiating agenda. In addition, ENGOs focused on getting or keeping issues on the agenda while business interests focused on keeping issues off the agenda (Burgiel 2008).

In the late 1990s, green business organizations began to develop and heavily invest in sophisticated public relations efforts and informal relationships with UN policymakers in a broadly acceptable green economy frame based on voluntary corporate actions. As a result, business sought and began to achieve privileged access to multilateral decision-makers, as evidenced by the strengthening of the green business organizations such as WBCSD. Corporate members of the WBCSD, heads of state and the UN SecretaryGeneral met in 1997 to establish business participation in the UN policy setting process and partnering in the use of UN development assistance funds (Korten 1997; Levy and Egan 2000:151). This led to the creation in 2000 of the UN Global Compact, a UN agency of corporations committed to sustainability.

Holliday (the then Chairman and CEO of DuPont and WBCSD leader) and colleagues portrayed the role of government in the well-known book, Walking the talk. Although they recognized the importance of government in many functions, they argued that corporate voluntary actions made government regulations unnecessary and that promoting a GE was a way to avoid regulations. They could not have been more explicit (Holliday 2002).

The support for this frame continued to improve and attract more supporters by favoring a broader albeit limited government role. One year later, Kell, Global Compact founder and leader, improved on this 
frame. In a press release, he said, "The Global Compact is meant to complement and not substitute regulation" (Kell 2003).

In preparation for Rio+20, UNEP, with corporate support, began to apply a strategy that helped overcome its intrinsic weakness in the UN family by greater involvement of private actors. UNEP held a Business and Industry Global Dialogue (Paris 2011), with about 200 ICC executives (Friends of the Earth International 2012; www.unglobalcompact.org/news/1871-05-21-2015; Weiss, T.G. et al. 2014).

Later, emulating NGO narratives, the Global Compact added even more detail to its view of government roles (UN Global Compact 2013).

One of the most significant trends in relation to corporate sustainability is the increasing involvement of the public sector, both in terms of regulation and soft policies to require or encourage better business practices.... Governments are increasingly adopting or considering pricing and other policies - especially in relation to natural capital - to create incentives for more responsible corporate behavior.

This posturing of a balanced position quiets many civil society opponents, bringing them, with inducements and partnerships, into a broad framing alignment. However, they avoid mentioning enforceable rules for those formal and informal businesses that do not follow the Global Compact principles and that fail to achieve the measurable impact that contributes to achieving SD including national emissions goals. Global Compact members generally subscribe to corporate social responsibility. But "self-regulatory steps do not prevent producers outside such agreements from adopting lower standards and cannot replace universal public regulation (Wapner 1996: 24)" "Not every situation lends itself to market instruments. In certain cases, welldesigned regulation, active technology-support policies, and voluntary approaches may be... an important complement to market instruments (Organization for Economic Cooperation and Development - OECD 2011: 12)." "Up to now, the plea for an adequate regulatory framework seems blind against dominant power relations (Brand 2012: 28)."

Green business organizations, scientific supporters and governments have placed the Green Economy frame in a positive light, giving the private sector a greater role in environmental policy. Meetings at all levels and highly reputable environment appointments represent this point of view. This thematic shift towards a business-oriented GE frame has succeeded, convincing some environmentalists and ENGOs to accept it. In terms of public policies, the difference between SD and GE appears to be essentially the regulatory role of the state and binding instruments. Leila Ferreira, interviewed to compare the influence of corporations, ENGOs, and scientists at Rio+20, recognized that shifting of the environmental debate to the green economy left out other important concerns (Manfredo and Costa Ferreira 2015).

Interpreting the limited evidence in the cited literature, Figure 3 suggests that CSOs and ENGOs had a low level of influence at Stockholm, increasing to high influence upon PrepCom prepared the Earth Summit documents and at the COP1 in Berlin, losing influence thereafter with divisions and disarray in the environmental movement. TNCs and green business organizations have had greater influence at climate change meetings, where they considered more was at stake. With the consolidation of the WBCSD and many other green business organizations, along with the creation of the Global Compact, TNC influence with governments and UN agencies increased at Rio+20 and at the COP21 Paris climate conference. We conclude that CSOs had greater influence at the Earth Summit than TNCs, declining at Rio+20 and Paris. 


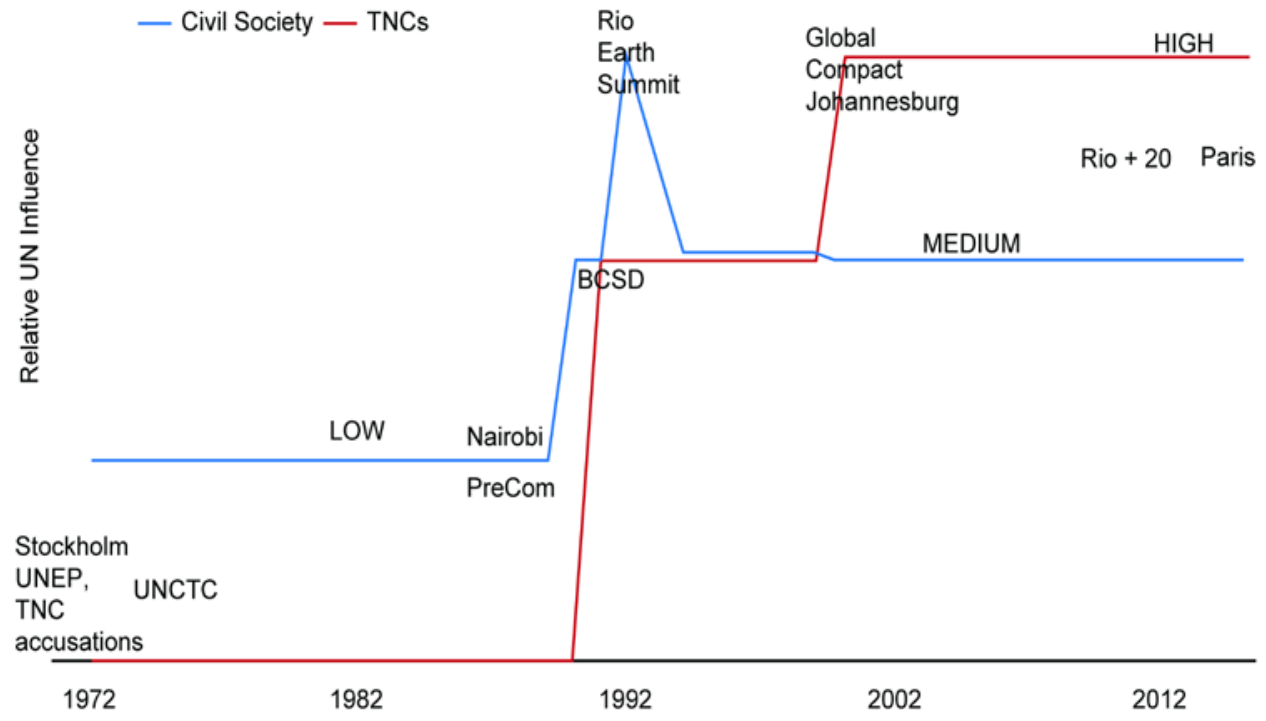

Figure 3: Relative influence of Non-State Actors (1972 - 2015). Sources: see Table 3. Note: Civil society's high influence at the Earth Summit on its documents, but moderate at UNFCCC.

\section{Shift in UN Conference objectives and outcome documents}

Changes in the narrative implicit in the wording of specific paragraphs in official U.N. documents, exclusively regarding the regulatory roles of the state and of the UN, reflect the growing influence of TNCs and the similarity with green business organization frames and narratives.

The declaration of the UN Conference on Human Development at Stockholm in 1972 indicated that states would have "the greatest burden for large-scale environmental policy and action within their jurisdictions" (UN 1972). Following the Earth Summit, the UN held the World Summit for Sustainable Development (or Rio+10) in 2002, at which the Johannesburg plan of implementation (JPOI) was prepared. In 2009, the UN decided to hold the United Nations Conference on Sustainable Development in 2012 (Rio+20). In May 2010, the Secretary-General presented a report at the first meeting of the conference's PrepCom. Two years later, Rio+20 was held in the context of an economic crisis. The host Brazilian government avoided negotiating differences in preparing the final outcome, which was entitled The future we want (United Nations 2012). It achieved global and country voluntary commitments, but did not set an accountability framework nor a performance reporting mechanism (ICLEI 2012).

This process reflects a clear but somewhat subtle change in the tone of the above UN conference documents regarding objectives. Text changes indicated a reduced role of the state in environmental policy (Table 5). At the Earth Summit, the objective was to "create a new world order for global cooperation on environment and development, emphasizing national and international public policies" (UN 1992) while recognizing the important roles of business and civil society. At Johannesburg, the objective was to "expedite the realization of the remaining goals by undertaking concrete actions at all levels" (UN 2002). There is clear evidence that the Rio+20 objective and text shifted from the Sustainable Development of the previous conferences to green economy at the Rio+20 (Weiss and Nascimento 2013).

In 1992 and 2002, the focus was endogenous capacity building, national regulatory and enforcement capacities, and property rights, extending even to the PrepCom document prepared by the Secretary-General's 
office in 2010, in the run up to the Rio+20 Conference. 'Governance' covered the role of institutions, processes, structures, principles, guidelines, integration, coordination and communication, as well as a framework to support the implementation of SD commitments at the global, regional, national, and local levels. They spoke of strengthening public institutions and enforcing laws.

In 2012, the Rio+20 agenda excluded all of those public policy concepts while retaining the objective to work towards SD and poverty eradication. Given the atmosphere of the recovering world economy, the political opportunity structure favored the Green Business Organizations which, with NS1 support, built a green economy frame of growth, technology and innovation, promoting the effectiveness of private voluntary actions. Regarding the state, The future we want only mentions the general need for institutions in $\S$ (paragraph)10 (United Nations 2012). In §76, it emphasizes the important objective of government efficiency, which possibly implies minimum state strategies. No mention is made of strengthening state capacity to enforce laws and implement integrated government, regulation, and control. Governance is reduced from global, national, and local levels to a secondary theme of an institutional framework for international organizations.

The COP21 in Paris reached an historical agreement in 2015 to contain climate change, but the Intended Nationally Determined Contributions (INDCs) are mere moral obligations, without legally binding commitments, reparations nor funding, unlikely to be implemented, as the world continues its 'business as usual' course. The Paris Accord preamble does refer however to an "enhanced capacity building framework, recognizing the importance of the engagements of all levels of government and various actors, in accordance with respective national legislations"... "which shall be enhanced through appropriate institutional arrangements (UN 2015, Article 11, §5)" and "non-market approaches shall aim to enhance public and private sector participation in the implementation of INDCs and enable opportunities for coordination across instruments and relevant institutional arrangements ( $\S 8$ of Article 6)." However, as most countries have been sold on the regulation-free green economy, other than reporting, government engagement will tend to be limited.

In addition to the reticent positions of many UN members, corporate leadership's privileged access to decision-makers over the years may have been one of the factors in sidelining the regulatory role of the state and legally binding instruments in UN declarations (Reis et al. 2015). This access may continue to influence national and local policies that affect emissions, including regulation, enforcement, market incentives and the role of NSAs. Thus, "voluntary codes may be seen as inadequate, leading to demands for greater government regulation" (Murphy 2005). 


\begin{tabular}{|c|c|c|c|}
\hline $\begin{array}{l}\text { the Earth Summit at Rio in } \\
1992\end{array}$ & $\begin{array}{l}\text { Johannesburg Plan of } \\
\text { Implementation (JPOI) }\end{array}$ & $\begin{array}{c}\text { Secretary-General, May, } 2010 \\
\text { PrepCom }\end{array}$ & The future we want $(\mathrm{Rio}+20)$ \\
\hline $\begin{array}{l}\text { OBJECTIVE } \\
\text { Create a new world order for } \\
\text { global cooperation on } \\
\text { environment and development. } \\
\text { SELECTED RIO } \\
\text { DECLARATION PRINCIPLES } \\
\text { 9. States should co-operate to } \\
\text { strengthen endogenous capacity- } \\
\text { building for SD. } \\
\text { 11. States shall enact effective } \\
\text { environmental legislation. } \\
\text { Environmental standards, } \\
\text { management objectives and } \\
\text { priorities should... } \\
\text { 13. States shall develop national } \\
\text { law regarding liability and } \\
\text { compensation for the victims of } \\
\text { pollution and other } \\
\text { environmental damage. } \\
\text { 16. National authorities should } \\
\text { endeavor to promote ... the use } \\
\text { of economic instruments } \\
\text { 17. Environmental impact } \\
\text { assessment, subject to a decision } \\
\text { of a competent national } \\
\text { authority. }\end{array}$ & $\begin{array}{l}\text { QUOTES } \\
\S 162 . \text { Establish or strengthen } \\
\text { existing authorities and mechanisms } \\
\text { needed to carry out, coordinate, } \\
\text { implement and enforce policies; } \\
\S 40,162-163 \text {. Promote national SD } \\
\text { through, among others, the setting } \\
\text { and enforcement of clear and } \\
\text { effective laws; } \\
\S 162 \text {. The States should promote } \\
\text { national institutions including the } \\
\text { strengthening of agencies and } \\
\text { policies, prepared by them, to } \\
\text { coordinate, implement and enforce } \\
\text { policies and laws, supported by } \\
\text { international cooperation. }\end{array}$ & 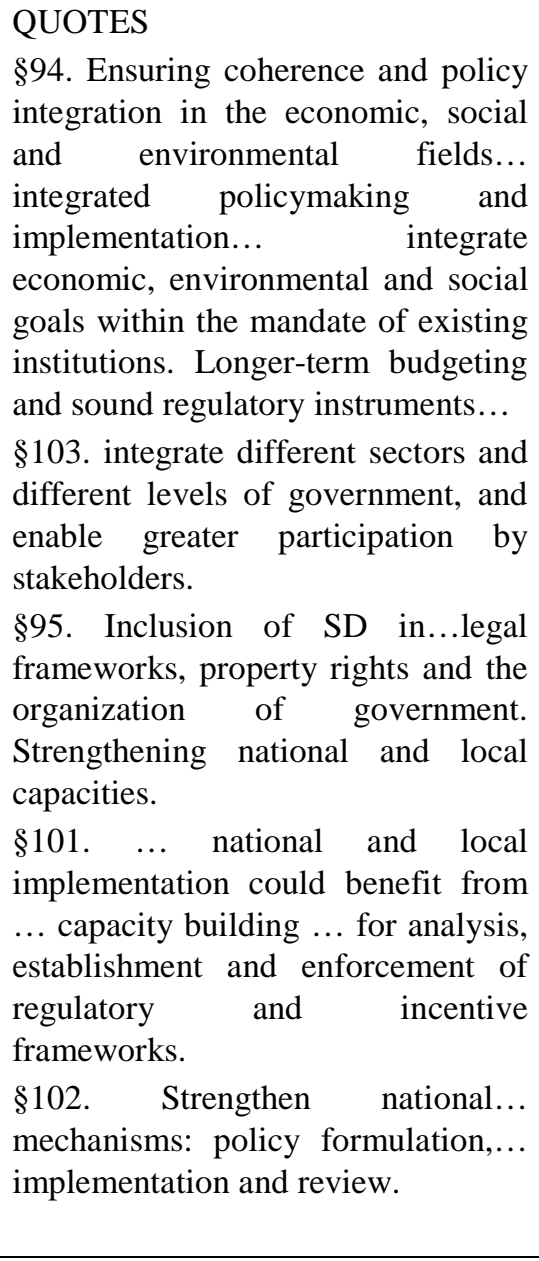 & $\begin{array}{l}\text { OBJECTIVE } \\
\text { Renewed commitment for SD } \\
\text { focused on two themes: (a) a GE } \\
\text { in the context of SD and poverty } \\
\text { eradication; and (b) the } \\
\text { institutional framework for SD. } \\
\text { QUOTES } \\
\text { §63. Promote GE in the context } \\
\text { of SD and poverty eradication, } \\
\text { with national regulatory, } \\
\text { voluntary and other measures; } \\
\text { §76. Selected from "institutional } \\
\text { framework": } \\
\text { (b) action and result-oriented } \\
\text { approach, cross-cutting issues } \\
\text { (c) interlinkages among key } \\
\text { issues and challenges, systematic } \\
\text { approach; (d) enhance } \\
\text { coherence, reduce fragmentation } \\
\text { and overlap and increase } \\
\text { effectiveness, efficiency and } \\
\text { transparency. } \\
\text { §193-197 and §268. Selected } \\
\text { from "Forests": sustainable } \\
\text { management of forests; non- } \\
\text { Legally Binding Instrument on } \\
\text { all types of forests; National } \\
\text { policies and regulatory } \\
\text { frameworks which promote } \\
\text { private sector development. }\end{array}$ \\
\hline
\end{tabular}

Table 5: Comparison of the role of the state in U.N. conference texts, 1992-2012 (regarding enforced regulation). Sources: UN (1992, 2002,

2010 and 2012). Note: See Paris Accord excerpts in text. 


\section{Inferences subject to further analysis}

In analyzing agency at the two UN environmental conferences, our comparison of green business organizations and ENGO influence at the Earth Summit in 1992 and Rio+20 in 2012, leads us to infer the following from the limited evidence available.

- At the Earth Summit in 1992, ENGOs had more influence, in terms of participating in setting the agenda, wording official documents, including Agenda 21, as well as supporting legally binding instruments, both through national governments and directly with UN agencies and conferences. However, TNCs had more influence at climate change INC meetings, where they realized more was at stake. ${ }^{5}$

However, we interpret that:

- At the 2012 Rio+20, given business' unified positions, GE narratives and years of change in UN architecture, it achieved greater access to national governments and UN agencies than did civil society, thus influencing agenda-setting, reducing the focus from sustainable Development to the Green Economy and limiting governance to 'global governance', reducing the role of the state in implementing environmental policies. This continued in Paris, even though the Accord contains some capacity-building rhetoric.

\section{Conclusions and final considerations}

UN institutions and positions have shifted in response to ongoing political mobilization among actors and have resulted in the redistribution of power among the UN political system's advocacy networks, changing the global political ecology without affecting UN stability.

Thus, Non State actor agency at the UN has gradually shifted from ENGOs to TNCs. Consistent with their improved access, TNCs shifted from a denier narrative to green economy frame which first prevailed at the Rio+20 Conference. This frame shifted world debate towards a private sector orientation, emphasizing economic growth, technology, and innovation. While ENGOs continue to put forward their agenda, green business organization rhetoric influence and match that of the state, determining higher-level decisions. This leaves aside the planet's major challenges, such as biophysical limits and production as well as consumption scales and patterns (Dasgupta 2011). Nationalism has now become an additional deterrent.

The shift in UN architecture and agency, with increased TNC and reduced CSO influence, has led UN documents away from effective regulation and control, reducing prospects for their implementation at the national level, as well as conditions for reducing emissions and increasing environmental justice (Beder 2000; Holliday et al. 2002).

Many economists agree that combining market mechanisms with strong regulatory frameworks is a best practice for environmental policy. When nation-states have the will and capacity to command and control, they can reduce environmental degradation, as shown in the case of deforestation in the Brazilian Amazon. Stronger national government competence and enforcement capacity is essential for the effectiveness of incentives such as reducing emissions from deforestation and forest degradation, and enhancement of forest carbon stocks (Angelsen and McNeill 2012, cited in Brockhaus and Di Gregorio 2014). When will and effort decline, degradation may return. Without a doubt, these combined measures can be even more effective when coordinated with appropriate business and civil society initiatives, as well as education to change behavior (Weiss, J.S. 2008; Weiss et al. 2007).

If civil society can reunite and regain its strength, not only through public protest, but also by negotiating with TNCs and the UN on equal footing, perhaps UN members could once again become comfortable with the idea of strong states and global governance, as the General Assembly achieved with the Ocean Conservation Treaty, consistent with Pope Francis' proposal for a legally binding climate treaty (Francis 2015: 173).

\footnotetext{
${ }^{5}$ Although not analyzed here, CSOs continued to influence document outcomes at Johannesburg and Monterrey in 2002.
} 


\section{References}

Adams Jr., T.I. and J. Martinez-Aragon. 2010. Setting the stage for the Earth Summit: Brazil. Environmental Law Reporter 22: 10190.

Almeida, F. 2003. O mundo dos negócios e o meio ambiente no século XXI. In Trigueiro, A. (ed.) Meio ambiente no século XXI. Rio de Janeiro: Sextante.

Angelsen, A. and D. McNeill. 2012. The evolution of REDD+: a political economy framework. In Angelsen, A. M. Brockhaus, W. Sunderlin and L. Verchot (eds.). Analysing REDD+: challenges and choices. Bogor Barat, Indonesia: Center for International Forestry Research.

Arts, B. 1998. The political influence of global NGOs: case studies on the Climate and Biodiversity Conventions. Utrecht: International Books.

Bai, X., S. der Leeuw, K. O'Brien, F. Berkhout, F. Biermann, E. Brondizio, C. Cudennec, J. Dearing, A. Duraiappah, M. Glaser, A. Revkin, W. Steffen and J. Syvitski. 2015. Plausible and desirable futures in the Anthropocene: a new research agenda. Global Environmental Change 39: 351-362. Academia

Beder, S. 2000. Global spin: the corporate assault on environmentalism. Melbourne: Scribe.

Biermann, F. 2015. Earth system governance: world politics in the Anthropocene. Cambridge: The MIT Press.

Biermann, F. et al. 2009. Earth System Governance: people, places and the planet. Science and Implementation Plan of the Earth System Governance Project. Bonn: IHDP. http://www.earthsystemgovernance.org/publications/2009/Earth-System-Governance_Science$\underline{\text { Plan.pdf }}$

Benson, E. S. Bass and O. Greenfield. 2014. Green economy barometer: who is doing what where, and why? Green economy coalition. London: IIED. http:/www.greeneconomycoalition.org/sites/ http://greeneconomycoalition.org/files/Green Economy Barometer.pdf.

Betsill, M. and E. Corell. 2008. NGO diplomacy: the influence of non-governmental organizations in international environmental negotiations. Cambridge: The MIT Press.

Brand, U. 2005. Order and regulation: global governance as a hegemonic discourse of international politics? Review of International Political Economy 12(1): 155-176.

Brand, U. 2012. Green economy - the next oxymoron? No lessons learned from failures of implementing sustainable development. GAIA - Ecological Perspectives for Science and Society 21(1): 28-32.

Brenton, T. 1994. The greening of Machiavelli: the evolution of international environmental politics. London: RIIA/Earthscan.

Brockhaus, M. and M. Di Gregorio. 2014. National REDD+ policy networks: from cooperation to conflict. Ecology and Society 19(4): 14.

Bryant, R.L. and Bailey, S. 1997. Third world political ecology. London: Routledge.

Burgiel, S.W. 2008. Non-state actors and the Cartagena Protocol on Biosafety in NGO diplomacy. In M. Betsill and E. Corell (eds.) Diplomacy: the influence of Non-governmental Organizations in international environmental negotiations. Cambridge, MA: MIT Press. Pp. 67-100.

Cavanagh, C. and T.A. Benjaminsen. 2017. Political ecology, variegated green economies, and the foreclosure of alternative sustainabilities. Journal of Political Ecology 24: 200-216.

Climate Action Network International. 2012. Ensuring Urgency to Act: elements of the Rio+20 Agenda. Input to the United Nations Conference on Sustainable Development. Rio de Janeiro: CAN.

Castro F. de and C. Futemma (eds.). 2015. Governança ambiental no Brasil: entre o socioambientalismo e a Economia Verde. Jundiaí, SP: Paco Editorial.

Climateandcapitalism.com. 2010. World People's Conference on Climate Change and the Rights of Mother Earth. South Branch Publications.

Corell E. and M. Betsill. 2001. A comparative look at NGO influence in international environmental negotiations: Desertification and Climate Change. Global Environmental Politics 1(4): 86107. Researchgate 
Cowles M.G. 1995. The 'Business' of agenda-setting in the European Union. Fourth Biennial International Conference of the European Community Studies Association. Charleston, South Carolina. http://aei.pitt.edu/6916/1/cowles_maria_green2.pdf.

Dasgupta, C. 2011. Reflections on the relationship between the 'green economy' and sustainable development. In UNCTAD (ed.) The road to Rio+20: for a development-led green economy. New York, Geneva: United Nations. Pp. 33-35. http://unctad.org/en/docs/ditcted20108_en.pdf

Dearing, J.W. and E.M. Rogers. 1996. Agenda-setting. Thousand Oaks, CA: Sage.

Della Porta, D. and L. Parks. 2014. Framing processes in the climate movement: from climate change to climate justice. In Dietz, M. and H. Garretts (eds.) Routledege handbook of the climate change movement. London: Routledge Pp. 19-30.

Dellas, E., P. Pattberg and M. Betsill. 2011. Agency in earth system governance: refining a research agenda. International Environmental Agreements 11: 85-98. Researchgate

Escobar, A. 1996. Elements for a post-structuralist political ecology. Futures 28(4): 325-343.

Egelston, A.E. 2013[2007]. Sustainable development: a history. Dordrecht: Springer.

Falkner, R. 2008. Business power and conflict in international environmental politics. New York/London: Palgrave Macmillan.

Falkner, R., H. Stephan and J. Vogler. 2010. International climate policy after Copenhagen: towards a 'building blocks' approach. Global Policy Journal 1(3): 1-11.

Francis. 2015. Laudato Sí. São Paulo: Paulus and Loyola.

Friends of the Earth International. 2012. Liberemos a ONU da captura corporative. Amsterdam: Friends of the Earth International.(www.foei.org).

Friends of the Earth International (FoeI) and Amazon Working Group (GTA). 1996. Coherent public policies for a sustainable Amazon. FoeI and GTA.

Gell-Mann, M. 2010. Transformations of the twenty-first century: transitions to greater sustainability. In H.J. Schellnhuber, M. Molina, N. Stern, V. Huber and S. Kadner (eds.) Global sustainability-a Nobel cause. Cambridge: Cambridge University Press. Pp. 1-8.

Global Governance Commission. 1995. Our global neighborhood. London: Oxford University Press.

Global Policy Forum. 2014. GBF Brief 1. New York and Bonn: Global Policy Forum.

Goffman, E. 1986. Frame analysis. Boston: Northeastern University Press.

Gupta, J. 2010. A history of international climate change policy. Wiley Interdisciplinary Reviews: Climate Change 1(5): 636-653.

Hajer, M.A. 1993. Discourse coalitions and the institutionalization of practice: the case of acid rain in Britain. In Fischer, F. and J. Forester. (eds.) The argumentative turn in policy analysis and planning. Durham: Duke University Press.

Hindess, B. 1986. Actors and social relations. In M.I. Wardell and S.P. Turner (eds.) Sociological theory in transition. London: Allen and Unwin.

Holliday C.O., S. Schmidheiny and P. Watts. 2002. Walking the talk: the business case for sustainable development. Oakland: Berrett-Koehler.

ICLEI. 2012. ICLEI's evaluation of the outcomes of Rio+20. Bonn: ICLEI. http://local2012.iclei.org/fileadmin/files/ICLEI_at_Rio_20.pdf

International Institute for Sustainable Development (IISD-KimoGoree). 1992. Prepcom IV: the final stop on the road to Rio, Earth Summit Bulletin 1 (27). http://www.iisd.ca/download/pdf/enb0127e.pdf.

Instituto Socioambiental (ISA). 2012. Comentário sobre o Rio+20. Brasília: ISA.

Johnson, H.G. 1979. The New International Economic Order. Selected Papers No. 49, Graduate School of Business. Chicago: University of Chicago.

Jones, M.D. and M.K. McBeth 2010. A narrative policy framework: clear enough to be wrong? The Policy Studies Journal 38(2): 329-353. 
Keck M.E. and K. Sikkink 1998. Activists beyond borders: advocacy networks in international politics. Ithaca: Cornell University Press.

Kell, G. 2003. Global Compact clarifies relations to norms adopted by Subcommission on Promotion and Protection of Human Rights. www.unglobalcompact.org/newsandevents/news_archives/ 2003_08_13.html.

Kell, G. 2005. The Global Compact: selected experiences and reflections. Journal of Business Ethics 59(12): 69-79.

Korten, D. C. 1997. The United Nations and the corporate agenda. Bainbridge Island, Washington: Living Economies Forum. http://davidkorten.org/pkortenuncorporate/

Klandermans, B. 1997. The social psychology of protest. Oxford: Blackwell.

Lago, A.A.C. do. 2007. Estocolmo, Rio, Johanesburgo: o Brasil e as três conferências ambientais das Nações Unidas. Brasília: Instituto Rio Branco; Fundação Alexandre de Gusmão.

Levy, D.L. and D. Egan. 1998. Capital contests: national and transnational channels of corporate influence on the climate change negotiations. Politics and Society 26(3): 337-362.

Levy, D.L. and D. Egan. 2000. Corporate political action in the global polity: national and transnational strategies in the climate change negotiations. In R.A. Higgott, G.R.D. Underhill and A. Bieler. (eds.). Non-State Actors and authority in the global system. London: Routledge. Pp. 138-154.

Lewis, P.A. 2002. Agency, structure and causality in political science: a comment on Sibeon. Politics 22(1): $17-23$.

Mahoney, J. and K. Thelen. 2010. Preface. In J. Mahoney and K. Thelen (eds.) Explaining institutional change: ambiguity, agency, and power. Cambridge: Cambridge University Press.

Manfredo, M.T. and L. da Costa Ferreira. 2015. Da Rio 92 a Rio+20: breve balanço crítico sobre os dois encontros. In F. Castro and C. Futemma (eds.). Governança ambiental no Brasil. Jundiai, SP: Paco Editorial. Pp. 263-284.

Martens, J. 2014. Corporate influence on the business and human rights agenda of the United Nations. Global Policy Forum/Misereor/Brotfürdie Welt.

Mintzer, I.M. and J. A. Leonard. 1994. Negotiating climate change: the inside story of the Rio Convention. Cambridge: Cambridge University Press.

Murphy, S.D. 2005. Taking multinational corporate codes of conduct to the next level. GW Law Scholarly Commons. Washington, DC: George Washington University. http://ssrn.com/abstract=627608.

Nasiritousi, N., M. Hjerpe and B.O. Linnér. 2014. The roles of non-state actors in climate change governance: understanding agency through governance profiles. International Environmental Agreements 16: 109126.

Nepstad, D. D. McGrath, C. Stickler, A. Alencar, A. Azevedo, B. Swette, T. Bezerra, M. DiGiano, J. Shimada, R. Seroa da Motta, E. Armijo, L. Castello, P. Brando, M.C. Hansen, M. McGrath-Horn, O. Carvalho and L. Hess. 2014. Slowing Amazon deforestation through public policy and interventions in beef and soy supply chains. Science 344 (6 June): 1118-1123.

Newell, P. 2000. Climate for change: non-state actors and the global politics of the greenhouse. Cambridge: Cambridge University Press.

Newell P. and M. Paterson. 2010. Climate capitalism: global warming and the transformation of the global economy. Cambridge: Cambridge University Press.

Nulman, E. 2015. Climate change and social movements: civil society and the development of national climate change policy. New York: Palgrave MacMillan.

Organization for Economic Cooperation and Development (OECD). 2011. Towards green growth. Paris: OECD.

Orr, D.W. 2017. The life required: political economy in the long emergency. In S. Shmelev (ed.) Green economy reader: lectures in ecological economics and sustainability. Basel: Springer. Pp. 3-23.

People's Summit. 2012. Final declaration. Rio de Janeiro. 
Peet R., P. Robbins and M.J. Watts (eds.) 2011. Global political ecology. London: Routledge.

Reis, T., A.C. Crisotomo, F. Bortolotto and P. Moutinho. 2015. De Lima a Paris, resultados da COP 20 e perspectivas para a COP 21. Belém: Instituto de Pesquisa Ambiental da Amazônia. Researchgate

Rising Tide North America. 2010. The climate movement is dead: long live the climate movement. Risingtidenorthamerica.org

Sagafi-nejad, T. and J.H. Dunning. 2008. The UN and transnational corporations, from code of conduct to global compact. Bloomington and Indianapolis: Indiana University Press.

Schmidheiny, S. 1992. Changing course. Cambridge: MIT Press.

Sikkink, K. 2002.Restructuring world politics: the limits and asymmetries of soft power. In Khagram S., J.V. Riker and K. Sikkink (eds.). Restructuring world politics: transnational social movements, networks, and norms. Minneapolis: University of Minnesota Press. Pp. 301-317.

Sibeon, R. 1999. Agency, structure and social chance as cross-disciplinary concepts. Politics 19(3): 139144.

Snow, D., A.B. Rochford Jr., S.K. Worden and R.D. Benford. 1986. Frame alignment processes, micromobilization and movement participation. American Sociological Review 51: 464-481.

Tarrow, S. 1998. Power in movement: social movements and contentious politics. $2^{\text {nd }}$ ed. Cambridge: Cambridge University Press.

United Nations. 1972. UN Conference on Human Development - UNCHD. Declaration of the Conference.

United Nations, WCED. 1987. Report of the World Commission on Environment and Development: Our common future. New York: UN.

United Nations, UN Conference on Environment and Development - UNCED. 1992. The Rio Declaration on Environment and Development. New York: UN.

United Nations. 2002. Plan of implementation of the World Summit on Sustainable Development or "Johannesburg Plan of Implementation - JPOI". New York: UN.

United Nations, Secretary-General. 2010. Objective and themes of the United Nations Conference on Sustainable Development. New York: UN. A/CONF.216/PC/7.

United Nations. 2012. The future we want. New York: United Nations.

United Nations Environment Program. 2012. Rio+20 Declaration on Justice, Governance and Law for Environmental Sustainability. Nairobi: United Nations Environment Program.

United Nations, Global Compact. 2013. Architects of a better world: building the post-2015 business engagement architecture. New York: UN Global Compact.

United Nations. 2015. Paris Agreement. New York: United Nations.

Wapner, P. 1996. Environmental activism and world civic politics. Albany: SUNY Press. ISBN13: 978-07914-2789-7.

Weible, C. M., P. A. Sabatier, H. C. Jenkins-Smith, D. Nohrstedt, A. D. Henry and P. de Leon. 2011. A quarter century of the advocacy coalition framework: an introduction to the special issue. The Policy Studies Journal 39(3): 349-360. Researchgate

Weiss, J.S. 2008. Introducción. In J.S. Weiss and T. Bustamante (eds.) Ajedrez ambiental, manejo de recursos naturales, comunidades, conflictos y cooperación. Quito: FLACSO. Pp. 11-26.

Weiss, J.S. and Nascimento E.P. do. 2013. Actors and trends in Brazil's anti-deforestation policymaking process (1979-2012). International Conference on Public Policy. Grenoble.

Weiss, J.S., G. Van Vliet and R. Pasquis. 2007. Factores que estructuran el diálogo sobre políticas ambientales en la Amazonía brasileña. In G. Fontaine, G. van Vliet and R. Pasquis (eds.). América Latina, en políticas ambientales y gobernabilidad en América Latina. Quito: FLACSO-IDDRICIRAD. Pp. 21-55.

Weiss, T.G. 2011. Global governance: Why? What? Whither? Cambridge: Polity Press. http://www.polity.co.uk/book.asp?ref=9780745660455. ISBN 978-0745660462

Weiss, T.G., T. Carayannis and R. Jolly. 2009. The "Third" United Nations. Global Governance 15: 123-142. 
Weiss, T.G., D.C. Seyle and K. Coolidge. 2013. The rise of Non-State Actors in global governance: opportunities and limitations. Discussion Paper. Bloomfield, CO: One Earth Future Foundation.

Weiss, T.G. and R. Wilkinson (eds.) 2014. International organization and global governance. London: Routledge.

WWF. 2012. WWF Rio+20 closing statement. Gland: WWF.

Zammit, A. 2003. Development at risk: rethinking UN-business partnerships. New York: The South Centre and United Nations Research Institute for Social Development. 